Rev. Leszek Marius Jakoniuk

University of Bialystok

\title{
Sprawozdanie z działalności Katedry Teologii Katolickiej Uniwersytetu w Białymstoku w roku akademickim 2019/2020
}

\section{Kadra}

W Katedrze Teologii Katolickiej UwB w roku akademickim 2019/2020 zatrudnionych było czterech pracowników. Trzech pracowników naukowych: ks. dr hab. Andrzej Proniewski na stanowisku profesora nadzwyczajnego (p.o. kierownika KTK) - cały etat, ks. dr Tadeusz Kasabuła na stanowisku adiunkta - 1/2 etatu, ks. dr Marek Kowalczuk na stanowisku asystenta - 1/2 etatu oraz ks. mgr lic. Leszek M. Jakoniuk (pracownik administracyjny w Katedrze Teologii Katolickiej) - cały etat.

\section{Działalność dydaktyczna}

W ramach działalności dydaktycznej pracownicy naukowi KTK przeprowadzili następujące wykłady:

\section{ks. dr hab. Andrzej Proniewski, prof. UwB}

- Tajemnice Wszechświata. Dialog nauki z wiara (wykład - 30 godz.) Wydział Biologii.

- Tajemnice Wszechświata. Dialog nauki z wiara (wykład - 30 godz.) Wydział Chemii.

- Tajemnice Wszechświata. Dialog nauki z wiara (ćwiczenia - 20 godz.) Wydział Nauk o Edukacji.

- Podstawy filozofii (konwersatorium - 14 godz.) Wydział Ekonomii i Finansów.

- Seminarium magisterskie (seminarium - 100 godz.) Wydział Nauk o Edukacji. 
- Wybrane zagadnienia z etyki (wykład - 10 godz.) Instytut Informatyki.

\section{ks. dr Tadeusz Kasabuła, adiunkt}

- Chrześcijańskie dziedzictwo Europy (wykład - 30 godz.) Wydział Historii i Stosunków Międzynarodowych.

- Elementy przedchrześcijanskie w kulturze pogranicza mazowiecko-litewsko-ruskiego (konwersatorium - 30 godz.) Instytut Studiów Kulturowych.

- Europejskość Europy (ćwiczenia - 30 godz.) Wydział Historii i Stosunków Międzynarodowych.

- Historia Rosji (konwersatorium - 30 godz.) Wydział Filologiczny.

ks. dr Marek Kowalczuk, asystent

- Bogowie i ludzie na Bliskim Wschodzie (konwersatorium - 30 godz.) Instytut Studiów Kulturowych.

- Judaizm. Historia i wspótczesność (konwersatorium - 30 godz.) Instytut Studiów Kulturowych.

- Judaism. History and present (konwersatorium - 30 godz.) Wydział Historii i Stosunków Międzynarodowych.

\section{Konferencje naukowe}

Katedra Teologii Katolickiej UwB w okresie sprawozdawczym była organizatorem konferencji naukowych:

- Aktualność sakramentu Eucharystii w duszpasterstwie - Konferencja naukowa, Białystok 4.01.2020.

- Warsztaty duszpasterskie dla księży Archidiecezji Białostockiej pt. Problematyka różnego rodzaju uzależnień (rozpoznawanie, profilaktyka), Białystok 18-19.02.2020.

oraz współorganizatorem konferencji naukowych:

- VI Dni Godności Życia (współorganizatorzy: Katolickie Stowarzyszenie Lekarzy Polskich O/Białystok, Hospicjum „Dom Opatrzności Bożej” w Białymstoku), Białystok 12.10.2019.

- Cykl Spotkań (I) ABC Wyszyńskiego, (współorganizatorzy: Studium Teologii w Białymstoku PWTW, Civitas Christiana, Klub Inteligencji Katolickiej, Instytut Pamięci Narodowej O/Białystok), Białystok 16.01.2020.

\section{Działalność naukowo-badawcza}

Pracownicy naukowi KTK UwB w ramach działalności naukowo-badawczej opublikowali efekty swojej pracy: 


\section{ks. dr hab. Andrzej Proniewski, prof. UwB}

Redakcja i współredakcja książek:

- Proniewski A. (red.), Między Wydziałem Teologicznym Uniwersytetu Stefana Batorego w Wilnie a Seminarium Duchownym w Biatymstoku, Białystok 2019, ss. 96.

- Proniewski A. (red.), Pasterze niezłomni i błogostawieni, Białystok 2020, ss. 143.

- Strankowski M. i in. (red.), Archidiecezjalne Wyższe Seminarium Duchowne w Białymstoku 1945-2020, Białystok 2020, ss. 104.

Rozdziały książek:

- Rola i znaczenie Wydziatu Teologicznego USB $w$ powstaniu seminarium $w$ Biatymstoku, w: A. Proniewski (red.), Między Wydziałem Teologicznym Uniwersytetu Stefana Batorego w Wilnie a Seminarium Duchownym w Biatymstoku, Białystok 2019, s. 23-35.

- Świadkowie wiary...nieugięci waleczni i święci, w: A. Proniewski (red.), Pasterze niezłomni i błogostawieni, Białystok 2020, s. 9-11.

- Biskup Wtadystaw Suszyński - duszpasterz i nauczyciel, w: A. Proniewski (red.), Pasterze niezłomni i błogosławieni, Białystok 2020, s. 65-76.

Artykuły naukowe:

- Reform of the Catholic Church, „Studia Teologii Dogmatycznej” 5(2019), s. 119-127.

- Joseph Ratzinger's (Benedict XVI) Conceptualization of Eternity, „Rocznik Teologii Katolickiej” 18(2019), s. 43-60.

Artykuły popularyzujące naukę:

- Powotanie do kapłaństwa wzrasta i dojrzewa $w$ seminarium duchownym, w: M. Strankowski i in. (red.), Archidiecezjalne Wyższe Seminarium Duchowne w Białymstoku 1945-2020, Białystok 2020, s. 45-94.

\section{ks. dr Tadeusz Kasabuła}

Współredakcja książek:

- Archidiecezjalne Wyższe Seminarium Duchowne w Biatymstoku 1945-2020, Białystok 2020, ss. 104.

Rozdziały książek:

- Stanistaw Bohusz Siestrzeńcewicz - pierwszy arcybiskup metropolita mohylewski, w: J. Wasilewski (red.), Od Maximis undique pressi do Totus Tuus Poloniae populus. Metropolie mohylewska i wileńska $w$ latach 1789-1992, Białystok 2019, s. 17-31.

- Deo et populo - arcybiskup Romuald Jatbrzykowski, w: A. Proniewski (red.), Pasterze niezłomni i błogosławieni, Białystok 2020, s. 77-89. 
- Różanystok w czasach staropolskich, w: J. Pietrzykowski, J. Wąsowicz (red.), Różanystok. W stulecie inspektorii św. Stanisława Kostki 1919-2019, Warszawa 2020, s. 17-24.

- Archidiecezjalne Wyższe Seminarium Duchowne w Biatymstoku. Dzieje, w: M. Strankowski i in. (red.), Archidiecezjalne Wyższe Seminarium Duchowne w Białymstoku 1945-2020, Białystok 2020, s. 9-44.

- Z dziejów terytorium parafii w Mońkach, w: M. Wróbel (red.), Parafia Matki Boskiej Częstochowskiej i św. Kazimierza w Mońkach 1920-2020, Białystok 2020, s. 19-28.

Artykuły naukowe:

- The Officials of the Cathedral Chapter of Vilnius Before the Partition of Poland, „Rocznik Teologii Katolickiej” 18(2019), s. 183-200.

- The Statutes of the Cathedral Chapter of Vilnius Before the Partition of Poland, „Rocznik Teologii Katolickiej” 19(2020), s. 67-81 [w druku].

\section{ks. dr Marek Kowalczuk}

Artykuły naukowe:

- Paradygmat koncyliarności w Dz 15, 1-29, „Studia Teologii Dogmatycznej" 5(2019), s. 69-83.

Artykuły popularyzujące naukę:

- Podróż mędrców za Gwiazda, „Drogi Miłosierdzia” 1(131)2020, s. $10-11$.

\section{Udział w konferencjach, zjazdach naukowych} i wydarzeniach kulturalno-naukowych, referaty

W roku akademickim 2019/2020 pracownicy naukowi, oprócz uczestnictwa w wydarzeniach organizowanych lub współorganizowanych przez KTK, wzięli udział w sympozjach, zjazdach, wernisażach:

\section{ks. dr hab. Andrzej Proniewski, prof. UwB}

- VIII Interdyscyplinarne Dni Świętego Tomasza z Akwinu: Apologia Eucharystii (Ełk 28.01.2020), referat: Cud eucharystyczny $w$ Sokótce $w$ świetle wiary $w$ Eucharystię.

\section{ks. dr Tadeusz Kasabuła}

- wernisaż wystawy „Wystawa (Nie)Wszystkich Świętych” (Białystok 29.11.2019, Archiwum i Muzeum Archidiecezjalne) - organizator.

- wernisaż wystawy malarstwa „Pasja” (Białystok 19.02.2020, Archiwum i Muzeum Archidiecezjalne) - organizator. 
- VI Dni Godności Życia, referat: Zabójstwo dziecka nienarodzonego $w$ dziejach cywilizacji europejskiej $w$ aspekcie historyczno-prawnym, Białystok 12.10.2019.

- Cykl Spotkań (I) ABC Wyszyńskiego, udział w debacie nt. Droga życia $i$ świętości Prymasa Kardynała Wyszyńskiego, Białystok 16.01.2020 - moderator spotkania.

\section{Studia Podyplomowe}

Katedra Teologii Katolickiej w roku akademickim 2019/2020 była organizatorem dwusemestralnych Studiów Podyplomowych Duszpasterstwo $i$ Zarzadzanie w Jednostkach Kościelnych dla 41 duchownych z Archidiecezji Białostockiej.

\section{Publikacje}

Nakładem Wydawnictwa Uniwersytetu w Białymstoku w ramach działalności KTK ukazały się następujące pozycje:

- Rocznik Teologii Katolickiej, Białystok 2019, t. 18 (20 punktów).

- Studia Teologii Dogmatycznej, Białystok 2019, t. V (5 punktów).

- Proniewski A. (red.), Między Wydziałem Teologicznym Uniwersytetu Stefana Batorego w Wilnie a Seminarium Duchownym w Biatymstoku, Białystok 2019, ss. 96.

- Proniewski A. (red.), Pasterze niezłomni i błogosławieni, Białystok 2020, ss. 143.

\section{Projekty}

Katedra Teologii Katolickiej jest w trakcie realizacji programu „Wsparcie dla czasopism naukowych”. Łączna kwota środków finansowych na realizację projektu wynosi $101300 \mathrm{zł}$.

\section{ks. dr Tadeusz Kasabuła}

1. Projekt nr WND-RPPD.08.03.00-209048116 pod nazwą „Ochrona i cyfrowe udostępnienie obiektów dziedzictwa kulturowego znajdujących się w zasobach Archiwum i Muzeum Archidiecezjalnego w Białymstoku" realizowanego w ramach Regionalnego Programu Operacyjnego Województwa Podlaskiego na lata 2014-2020 - kierownik projektu. 